that through pressure caused by the increased amount of cerebrospinal fluid there may he palsy of different cranial nerves. This is undoubtedly the explanation for the paralysis of the external recti muscles and the possible weakness of associated movements present in our case.

\title{
CHRONIC ANTERIOR POLIOMYELITIS, WITH THE REPORT OF A CASE WITH NECROPSY.
}

\author{
By Geonoe A. Moleen, M.D.,

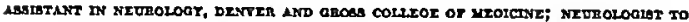

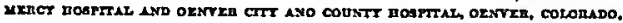 \\ AND \\ WIILAM G. SPLLER, M.D.,

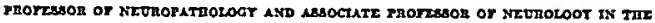

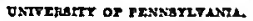 \\ - From the Deaver and Grose College of Sfediclne and trom the Neuropathologleal Laborators \\ of the Undrenity of Pennsylvanin.) \\ CLINICAL NOTES AND REMSARKS BY DR. MOLEEN.
}

OwING to the diversity of opinion with reference to the classification of spinal-cord lesions attended with muscular wasting, with or without spasticity, and with or without the presence of the deep or tendon reflexes, the assigning of the following case presents a somewbat difficult problem, and for this reason it is deemed wise to first detail the clinical notes of the case before discussing tbose points, which, to the author, were obstacles in arriving at an appropriate clinical diagnosis.

J. Ten WV., aged thirty-seven years, lahorer, thougb he did mostly upbolstering work, was first seen October 3,1903 , at wbich time the following notes were made: He was horn in St. Clair, Minn., but bas been in Colorado six or seven years, and did not come for his health.

Family History. He denies all diseases of childhood, except measles, whicb he had at the age of ten years. He was perfectly well until 1890, when be bad an attack of la grippe, and he bad another in Colorado three years ago. His calloused hands bear him out in the statement tbat be bas done bard work, and be says that he has been exposed in the mountains to sough weather until a few years ago, thougb be denies rheumatism or pneumonia. He admits baving contracted gonorrhœe, but firmly denies syphilitic infection. It may be stated, however, that a physician related to him informs me that he treated him for syphilis twenty years ago.

Present History. About two weeks ago, without chill, pain, cold, fever, numhness, or the sligbtest symptom of an acute character, 
he noticed upon arising in the morning that his left foot felt heavy and that he was "limping."

He insists that he was perfectly well at the time and that the weakness was his only cause for complaint. He is certain that he is no worse to-day than when he first noticed his trouble. He has no diffieulty in passing his urine nor in emptying his bowel.

Fı. 1

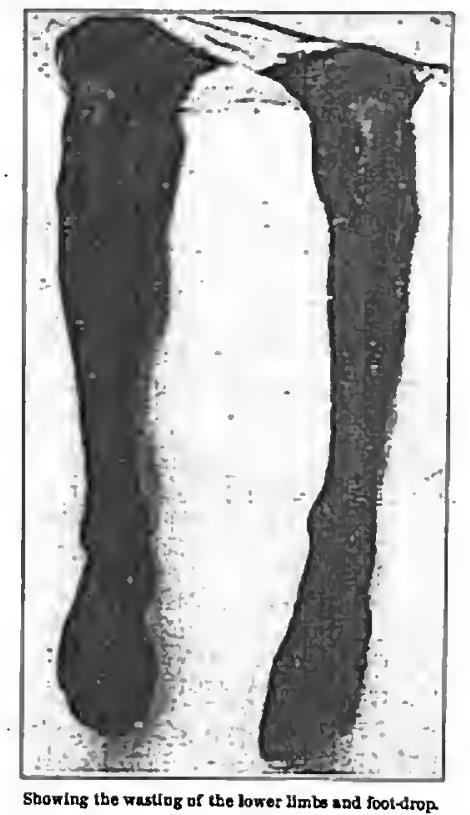

Examination, October 6, 1903, gave the following results:

$\mathrm{He}$ is a short-five feet, three inches-wcll-devcloped man, though he shows his age and hard work. His weight is 120 pounds. - In walking the left foot is raised considerahly higher than the right, and with a jerky exaggerated lexion of the knee the foot is planted squarely on the floor with a tendency to strike the toe first.

Standing with the eyes open and the feet together, there is no perceptihle swaying, which is but slight when the eyes are closed. 
In the sitting posture, with lower limbs hanging, the "foot-drop" is noticeahle on the left side.

There is no ataxia in the arm nor trunk muscles.

The calf of the left leg is somewhat atrophied and the muscles flaccid, though especially noticeahle is the wasting of the muscles supplied hy the peroneal nerve. The dorsum of the left foot, from the promincnce of its tendons, seems more wasted than the right.

The circumference of the largest part of the calf: right, 123 inches; left, $11 \frac{1}{2}$ inches. Of the thigh: right, $17 \frac{1}{2}$ inches; left, $15 \frac{3}{4}$ inches.

Electrical reactions: Galianic hattery is out of order and reactions cannot be taken. Faradic irritahility is greatly diminished in the lower part of the left leg, otherwise it is normal throughout this limh. With the slowly interrupted current no contraction of the muscles supplied by the peroneal nerve can be obtained, even with the strongest current.

Reflexes: Knee-jerks, right is increased, especially on reinforeement. Left is slightly more increased than the right, hut the kneejerks were not increased to the degrec commonly observed in spastic paralysis. Ankle elonus is absent. Tendo Achillis reflex: Right is present and ahout normal. Left is ahsent.

Deep reflexes of the forearm, flexors and extensors: Right are present. Left also and slightly increased. Biceps, triceps, and deltoid, same. Dynamometer (Tiemanin, inner scale): Right = 280; left $=280$. The man is right-handed. Masseter reflex is absent. - Superficial reffexes: Plantar: right is present; left is very slight. There is no evidence of the Bahinski phenomenon. Cremasteric reflex: Right is present; left also is present, though not so marked as right. Lower abdominal refex: Right is slight; left is very slight. Epigastric reflex is present.

17. Sensory phenomena are normal throughout the hody (tactile pain, pressure, temperature, and postural senses taken).

Special senses: Eyes, all external ocular motion is normal and without nystagmus. Pupils are equal and respond actively to light and accommodation. Fields of vision are apparently normal. Fundi: There are no retinal changes, and the disk is well outlined in either eyc. Hcaring (watch): Right $=6-24$; left $=8-24$. The tuningfork is heard best in the closed ear, and aerial conduction is greater than that of hone. Taste and smell are seemingly not impaired. The tongue is protruded in the median line, without tremor, and there is no difficulty in speech.

A diagnosis of anterior poliomyelitis was made at this time and he was under ohservation until January, 1904. During this time there was no apparent change in his condition, and it may he said that, though repeatedly examined, there was no wasting to be noticed in the hand nor in any other part of the body, nor was 
fihrillation to be seen at any time, these symptoms having been expected hecause of the ahsence of improvement.

1 . He was not seen again until January 21,1905 , when the following notes were taken:

The face is apparently drawn, probahly due to emaciation, and moderate emotion (laughter) is not evidenced in the facial expression. All voluntary motion of the facial muscles, though weak, is equal on the two sides. The tongue is protruded ahout half an inch heyond the incisor teeth, shows a decided fihrillary tremor throughout, and is markedly furrowed from wasting. It is protruded in the median line.

He responds correctly to questions asked him, though with very slow enunciation, drolling all words requiring the usc of the pharyngeal and lahial muscles, but more particularly the lingual.

He states that six weeks ago he "had his palate cut" (referring to the uvula), from which time he noticed difficulty in strallowing and speaking.

Fra. 2

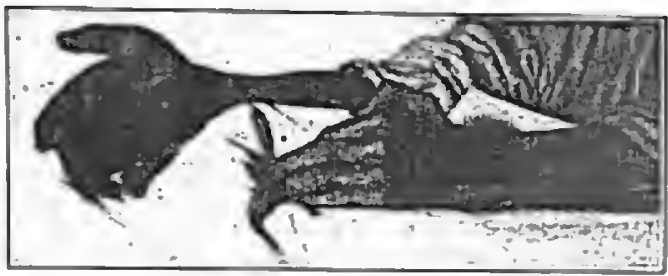

Sbowing the resting of the bands and forearme

There is to be noticed in the most prominent muscles-e. g., biceps, deltoid, pectoral, gluteal, etc., linear depressions parallel to the muscle fihres, apparently wasted strands, hetween which lines of twitching are to he seen. This twitching is also to he plainly seen in the spinal muscles. Tapping the muscles increased the frequency though not the degree of the twitching.

The grentest wasting is to be ohserved in the hand muscles on hoth sides, more particularly the adductors of the thumb. The thenur and hypothenar eminences are complctely wasted, and on extending the hands a decided, somewhat coarse tremor of the right thumh is noticeable (Fig. 2).

The left lower extremity is smaller in size than the right, and the group of muscles innervated by the left peroncal nerre is entirely wanting.

Plantar flexion of the left foot is somewhat weaker than of the right, while no dorsoflexion of the left foot can be aceomplished. 
The muscular strength in the shoulder, arms, and forearms is fairly well preserved and equal. Dynamometer, right $=110$; left, $=100$.

The man walks raising the left knee markedly higher than the right, and the left foot is swung farther forward and placed flatly on the floor and turned slightly outward. His gait is little if at all altered upon closing the eyes. $\mathrm{He}$ is ahle to stand with the feet together and eyes open, though he sways slightly, and the swaying is somewhat increased when the eyes are closed. The increased effort in the latter instance seemingly excites a fine tremor of the face and neck muscles.

The arm and trunk muscles are free from ataxia...

Measurements of the extremities: Arms, 4 inches above the olecranon; right $=87$ inches; left $=8 \frac{1}{4}$ inches. Arms, 4 inches below the olecranon; right $=8$ inches; left $=7 \frac{1}{2}$ inches. Legs, 4 inches helow thial tuherosity; right $=103$ inches; left $=91$ inches. Thighs, 8 inches helow anterior superior spine, right $=15$ inches; left $=12 \frac{1}{2}$ inches.

Electrical reactions: galvanic (chloride of silver fifty-cell battery was used, sponges moistened in alkaline tepid water, and interruptions made with the handle; current strength in milliamperes):

Tibialis anticus: right, $\mathrm{KaClC} 10, \mathrm{KaOC} 10$, AnClC none, AnOC none; left, no respouse to the strongest current; peronei same.

Tihialis posticus: right, $\mathrm{KaClC} 6, \mathrm{KaOC} 12, \mathrm{AnClC} \mathrm{10,} \mathrm{AnOC}$ none; left, $\mathrm{KaClC} 2, \mathrm{KaOC} 3, \mathrm{AnClC} 5, \mathrm{AnOC} 20$.

Flexor carpi radialis: right, $\mathrm{KaClC} 2, \mathrm{KaOC} 15, \mathrm{AnClC} \mathrm{6}$, AnOC 25; left, KaClC 2, KaOC 20, AnClC 3, AnOC 15.

Extensor communis digitorum: right, $\mathrm{KaClC} 4$, AnClC 3; left, $\mathrm{KaClC} \mathrm{4,} \mathrm{AnClC} 2$ (weaken rapidly).

Both the right and left deltoid muscles give anodal and cathodal contractions at 3 milliampères.

Masseters are equal: $\mathrm{KaClC} 1 \frac{1}{2}, \mathrm{AnClC} 3 \frac{1}{2}$. Sternocleidomastoid muscles are equal: $\mathrm{KaClC} 2, \mathrm{AnClC} 3$.

There can be no responses obtained from the thumb muscles of either hand with the strongest currents.

Faradic: (No. 8 ehloride of silver battery, No. 2 secondary coil, 26 wire; two cells in circuit and current strength indicated in fractions of the rheostat circumference, unless otherwise indicated).

Tibial is anticus: Negative, right, $\frac{1}{3}$; left, none with full eurrent. Positive, right, $\frac{1}{2}$; left, none with full current.

Rapid interruptions the same.

Tihialis posticus: Right, $\frac{1}{2}$; left, $\frac{1}{2}$ (negative).

Extensors of both legs respond equally to $\frac{1}{2}$; flexors, $\frac{7}{3}$.

Flcxor communis digitorum: left, $\frac{1}{3}$; right, same.

The muscles of both arms and forearms show an increased irritahility. Facial muscles are about normal, electrically. 
Refexes: Knee-jerks, right, increased; left, also. The effect is little changed by reinforcement. A slight aokle elonus of short duration is present in the right foot, whieh is very easily exhausted. Left ahsent. Deep reflexes of the forearm: Flexors and extensors preseot, those of the left side are seemingly more pronouneed than those of the rigbt side. Bieeps, triceps, deltoid, aod pectoral reflexes are present. Masseter refex is absent.

Superficial refexes: Plaotar, right is present; left is abseot. There is no evidenee of the Babinski pheoomenon, and the dorsal foot refex lately deseribed by Meodel ${ }^{1}$ is oegative. Cremasteric reflex: right is slight; left is absent. Lower abdominal refex apparently is absent. Epigastrie refex is slight.

All sensory phenomena (tactile, temperature, pain, pressure, and postural) are normal and equal.

Owing to laek of control of the tongue, it is diffieult to accurately test the sense of taste, though it is seemingly normal, as is also the sense of smell.

Eyes: Pupils are equal and respond equally to light and accommodation. Ocular motion is equal in all directions. The fields of visioa (taken with the hand) arc evidently not eontraeted. The disks, while pale, show no degeneration and the vessels are not changed.

Hearing is about as previously recorded.

The foregoing notes were taken during several examinations made between January 21 and 29, 1905, to which the followiog general observations may be added: Ioability to eontrol emotion; the extremes only were cvident in the facial expression; slight laughter was often followed hy tears without provocation; increasing dysphagia and dysarthria; increasing diffieulty in coughing and expectorating apparently due to laek of control of the respiratory, pharyngeal, and lingual muscles.

When seen January 29, 1905, at 1 P.3t., the temperature was $99.5^{\circ}$ aod pulse 100 , and be was sleeping quittly. Refusiog nourishment, he slept the greater part of the afternoon, death taking place at 7 P.ar. of the same day, the increase in pulse and respiration rate and volumc being the only change notieed, the attendants are certain, however, that no marked ehanges in respiration ( $c . g$., laryngeal spasm, Chejne-Stokes breathing) were to be noticed.

Autopsy was made three hours after death. The examination was limited to the spinal eord and brain. The body was quite warm. The spinal eord and brain were removed, the cerebellum, brain stem and cond being retained for examination. The membranes were not adberent, no vascular change was noticed, and the ventrieles were apparently normal. No gross changes were ohserved in the eerehral hemisphcres. The retained portions were submitted to Dr. William G. Spiller for examination.

I K. Mendel Nerologiteches Ceatniblett, 1904, T. xxil, No. a. 
SUmasarr. A man, aged thirty-seven years, prohably syphilitic, is afflicted withsudden paralysis of the group of muscles innervated hy the left peroneal nerve; complete loss of faradic irritahility followed in a week, and this was followed by rapid wasting and slight diminution in size of the entire leg; the deep reflexes were present and increased, but not excessively, and in that spinal segment represented hy the absolute a trophy they were lost; the symptoms were confined to the left lower extremity and were without cbangeduring three months; no fihrillary tremor, sensory disturhance, hand weaknesses, nor cranial nerve symptoms were present. One year later there were slight general emaciation, complete wasting of the thenar and hypothenar eminences, and, to a less extent, of the interossei muscles; atropby and paresis of the tongue and pharynr, fihrillation throughout the hody, including the tongue, and tendon refexesstill moderately increased. There were no marked electrical changes, except in absolutely wasted muscles, and no hladder, bowel, nor sensory disturbances. He was becoming more emotional, dyspbagic and without dyspnca, though he had a rapidly increasing pulse and respiration.
Termination was dcath.

When first observed the reconding of the case as acute anterior poliomyelitis, in view of the rapid onset and the absence of evidence of involvement of other portions of the cord, was justifiable. The only points apparently opposed being the age of the paticnt and the absence of prodromes or febrile disturbance.

The fact that no evidences of extension nor involvement elsewhcre could be noticed after three months seemingly supported this
diagnosis.

When, bowever, wasting of the hands, fibrillation, dysarthria, and dyspbagia were added after the lapse of a year, one would be justly suspicious of $(a)$ progressive spinal muscular atrophy (especially a peroneal type), (b) amyotrophic lateral sclerosis, or (c) chronic poliomyelitis - three conditions whicb bave heen considered by some authorities as synonymous-the extremely wide variations in individual cases notwithstanding.

It seems pretty well establisbed that in pure cases of progressive spinal muscular atrophy the wasting invariahly precedes the paralysis, and certainly the great majority of cases first manifest weakness in the bands (nine-tenths, acconding to Gowers). Conspicuous also is the advent of fibrillary twitching in the gradually weakening muscles, as well as in those about to be attacked, in which the weakness had not heen noticed, and in any event hefore paralysis had supervened.

The electrical reactions in these cases of progressive spinal muscular atropby persist until the wasting is intense.

Clinically, perhaps, this case more closely conforms to the type known as "peroneal," whicb since the thesis of Dr. Tooth and the ohservations of Dr. Hoffmann, has, in the opinion of most authorroL. 130, ко. 6.-DrcxuBEr, 1005. 
ities, merited a separate classification, and some have referred to it as "neuritic" (perhaps more properly "neurotic," from the "Progressive Ncurotische Muskelatrophie" of Hoffmann), in view of its occurrence in several members of the same family, in the majority of instances. That it occurs, as a rule, in the second half of childhood-i. e., before the twentieth year of life, seems to be generally accepted, though Oppenheim thinks the commencement may he as late as the fourth decade.

Some observers have used the term "neuritic" advisedly, because of the belief that the periphcral nerves are primarily affected. This is questioned by Dana, wbo believes the cord to bc first attacked, and quotes Marinesco as having recently confirmed this view, mentioning a citation hy the same author of a case beginning as a "typical acute anterior poliomyelitis."

As rather against than for the placing of this case under this beading, the following features deserve mention: The occurrence of the disease earlier in life as a rule; usually hereditary involvement; frequent scnsory disturbances (pain, numbness, etc.); usually abolition of the tendon reflexes in the extremity affected; slow development; atrophy usually extreme; lastly, conspicuous by its absence in the cases reported is the mention of bulbar symptoms.

As tersely expressed by Dana, the hereditary or "leg type" of progressive muscular atrophy is characterized by its beginning in the legs, by much sensory disturbance, typieal degeneration reactions and hereditary or family history.

Is this a case of amyotrophic lateral sclerosis?

It is well before considering this condition to disregard the question of synonymy, and with Oppenheim, Dana, Beevor, and others, retum to the original distinetive classification of Charcot. This disease occurs most frequently after thirty, romen being more often affected than men; in truc types the hands are first affected, and the spasticity is marked; the first symptom is usually rigidity; clonuses, including a masseter clonus, are frequent; flaccid paralysis never inaugurates the discasc, and the onset is nearly always gradual. Oppenhcim only records an acute beginning; as a rule, cacb muscle wastes very gradually.

In the study particularly of the clinical side of the case, however strong our convictions may lead us to the heading of progressive muscular atrophy, the consideration of the distinctive points of the third of the "trio," chronic anterior poliomyclitis cannot be overlooked. This line of distinction, one must ardmit, in the ligbt of our present knowledge, is as yct fine.

While partial recovery is the rule, though more especially in the acute form of anterior poliomyelitis, yet cases do become subacute or chronic, and extension or probably the independent involvement of other segments, including tbe bulb, are tben not uncommon, and in fact bulbar paralysis very frequently closes the scene in all three 
of the conditions mentioned-viz., progressive spinal muscular atrophy, amyotrophic lateral sclerosis, and chronic anterior poliomyelitis.

In chronicanterior poliomyelitis the paralysis precedes the wasting, the palsy is ahsolute, flaccid, without rigidity, and involves groups of muscles physiologically related, while in the other affections previously considered the muscles concerned are anatomically related. Syphilis is a frequent cause in advanced life of the chronic cases; all electrical irritahility is rapidly lost in the group of muscles affected, and neighboring muscles are altered in proportion to the degree of subacute extension, this alteration hecoming less marked farthest from the cord representation of the principal group involved. A predilection of the peroneal group in all cases of anterior poliomyclitis is notahle.

The mention of fihrillary twitching has been purposely omitted heretofore, for the renson that it is seemingly common to all chronic muscular atrophies, and Gowers, in his hroad view of the three disenses as one, states that it is not invariahle, nor is it confined to this disense; and Oppenheim has to say: "Progressive muscular atrophy can never he diagnosed from fibrillary tremor, as this symptom may occur in healthy persons after excesses, in emaciated individuals when exposed to cold, and in neurasthenic and hypochondriac paticnts."

While disposed to rest the diagnosis here, I am constrained to admit that against this disposition is the presence or ineressed activity of the deep reflexes which in the cases previously reported as such was ahsent; the explanation offered with reference to the electrical alterations in the segments immediately adjacent to the actual lesion, it is reasonable to suppose, will hold good here, and possibly estahlish a point of distinction with future ohservation.

It is therefore evident that while no resting place is ahsolutely fitted for the reception of this particular case, the wide latitude of which chronic anterior poliomyelitis admits, and the fact that here are found fewer opposing factors than in the other mentioned conditions render its placing here at least permissible.

The emotional symptoms at the close of the casc are, as noted hy Dana, common evidences of bulbar lesions, either primary or secondary.

PATHOLOGICAL NOTES AND RFMARKS BY DR. SPILLER.

The case which Dr. Moleen has studied clinically so carefully is worthy of the attention he has given to it. I know of no case with necropsy like it in American or English literature, and it should, therefore, he of value in the study of the muscular atrophies. This is a subject that is still causing much difficulty in classification. The commencement of the symptoms in Dr. MIoleen's patient with 
peroneal palsy, resembling the neurotic muscular atrophy, is characteristic of certain lesions of the cells of the anterior horns. Baumann, ${ }^{1}$ in a clinical study of 85 cases of acute anterior poliomyelitis, has shown that the muscular supply of the peroneal nerve is especially liahle to become paralyzed in this disease.

Dejerine $^{2}$ reviews the opinions held regarding motor localization within the spinal cord. According to him, it is not segmental (hand, forearm, arm), as Van Gehuchten and De Buck believed; it is not diffuse (Marinesco), each muscle is not separately represented (Sano), hut the localization is of the root typc. An examination of the diagram given hy Dejerine, p. 780, shows that the peroneal supply is represented in the fourth and fifth lumbar and first sacral segments. We can, therefore, understand why, in Dr. Moleen's patient, the paralysis began in the peroneal group.

My report is as follows:

Only the spinal cord and hrain stem of this case were sent to me for examination.

Lumbar Region. The white matter by the Weigert hematoxylin stain does not appear to be degenerated. The small vessels of the anterior horns are much congested and are, therefore, very prominent by this stain. Those of the posterior horns are also congested, but not so much so as are the vessels of the anterior horns. Small hemorrhages are numerous in the gray mattcr, especially in the anterior horns, hut are also present in the posterior horns. The posterior roots are well stained. The anterior roots of the lumbar and sacral regions show in places distinct degeneration, but these roots are fur hetter preserved than are the cells of the anterior horns. There is no round-cell infiltration within the spinal cord or pis. The nerve cells of the anterior horns are much diminished in number, but those that still persist appear to be almost normal, and only occasionally one is seen showing chromatolysis, displacement of the nucleus, or much pigmentation. A slight recent degeneration in the crossed pyramidal tracts is seen only by the Marchi method.

Middle Thoracic Region. Small hemorrhages are numerous in the gray matter, in the posterior as well as in the anterior horns, and are found, hut much less numerously, in the white matter near the gray. The Marchi method reveals a very slight degeneration of the crossed pyramidal tracts and a few scattered hlack dots elsewhere in the anterolateral columns.

First Thoracic and Eighth Cervical Segments. The small hemorrhages are very numerous in the anterior and posterior horns, and ane found also in the whitc matter near the gray. In this portion of the cond the nerve cells of the anterior horns have almost disappeared. There is hemorrhage also within the pia, hut nowhere is there any round-cell infiltration.

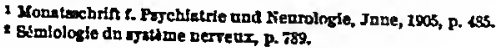


Bfedulla Oblongata. Small hemorrhages are numerous here also. Intramedullary fibres of the twelfth nerve have disappeared by degeneration. Unfortunately the nuclei of the twelfth nerves have been injured at the time of the necropsy, but a marked disappearance of nerve cells in these nuclei may be determined. The nucleus ambiguus contains few cells. The intramedullary fibres of the ninth and tenth nerves are much atrophied. A very slight degeneration of the anterior pyramids is seen only hy the Marchi method

Fro. 3

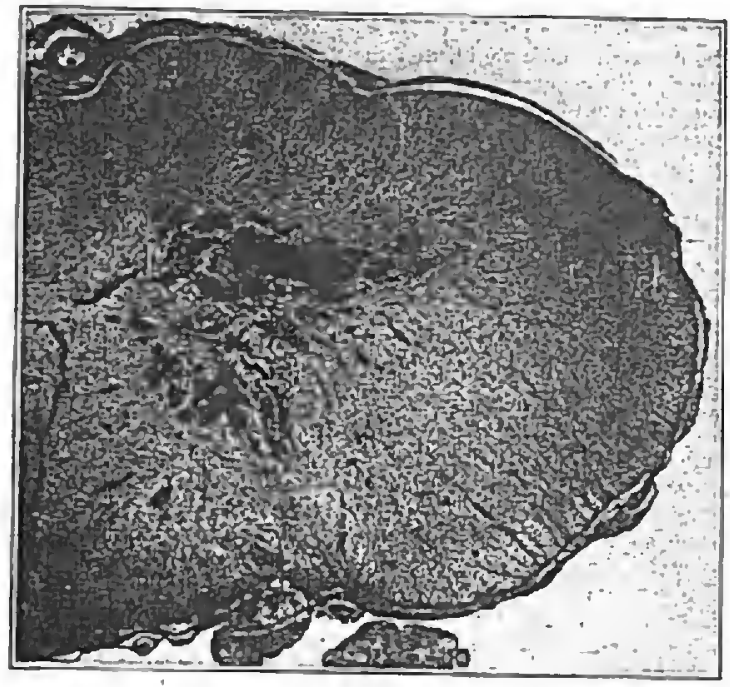

Showing the numerous bemorrbages kitbin the gray instter of the optnal cond.

and is less than the degeneration of the crossed pyramidal tracts of the spinal cord.

There are few cells in the nuclei of the seventh nerves and the intramedullary fibres of these nerves are much degenerated. Small hemorrbages are not so numerous in the pons. The cells still persisting in the facial nuclei stain fairly well, except that bere and there a cell may be found distinctly degenerated.

A few small hemorrhages are found in the cerebral peduncles, 
The important alterations in this case are disappearance of many of the nerve cells of the anterior horns of the spinal cord and motor cranial nerves in the medulla oblongata, of the anterior roots of the lumbar and sacral regions (cervical region was injured), and of the motor nerves of the medulla oblongata, and numerous small hemorrhages is the gray matter, especially in that of the spinal cond.

It is very questionahle whether we should make sharp distinetions between cbronic anterior poliomyelitis and progressive spinal muscular atrophy. In the first the paralysis is supposed to develop witbin a few days or a feri weeks, the atrophy appears later, and entire muscles or groups of muscles are paralyzed, the course of the disease is more rapid, and the paralysis develops first in the muscles of the lorer limbs or shoulders. In the progressive spinal muscular atrophy the paralysis is proportionate to the atrophy, one muscle fibre after another is affected, and the course is longer than in the chronic poliomyelitis. These are distinctions that are not always regarded, and it is very evident that some of the reported cases of so-called chronic anterior poliomyelitis might just as well he labelled as examples of progressive spinal muscular atrophy:

The cases of either type with necropsy are very rare. To Oppenhcim the credit of reporting the first typical case of chronic poliomyelitis with necropsy has been justly given. In Oppenheim's ${ }^{2}$ first case the wcakness began in the right arm. The ressels of the cond wcre not distinctly altered.

In the case that S. G. Webber ${ }^{2}$ reported in 1875 meakness began in the left knee and soon the left leg gave out. Atrophy did not appear until after the weakness. Sensatioa was not affected. The nerve cells of the cervical region were much diseased and were not numerous. There was some perivascular bulbar infiltration. The white matter of the cord appeared as a homogeneous mass, not coloned by carminc; occasionally an axis-cylinder could he seen. The lumbar and tboracic portions of the cord could not be satisfactorily studied. The ncrve cells of the hypoglossal-nuclei were few in aumber and many axis-cylinders were swollen. The posterior and antcrior roots were also affeeted.

This case is important, as it nas reported about thirty years ago, and clinically seems to have preseated the symptoms of chronic anterior poliomselitis, but pathologically it appears to have heen a case of diffuse myelitis. The duration of the symptoms was ahout one year.

It is true that Nonne ${ }^{3}$ included as cases of subacute anterior poliomyclitis those reported by Eiscnlohr, and Landouzy and Dcjerinc, and as a casc of chronic anterior poliomyelitis the case

1 Archir f. Frychinte, 1888, Bd. xIx. n. s81.

- Transuctions of the American sieurolorfcal Association, 1875, p. 35.

- Detische Zeltachtif f. Nerreabetrzande, 1591, Bd. L. p. IS6. 
of Dreschfeld. These three cases he acknowledges were very different from one another, and he makes three types of chronic anterior poliomyelitis: 1. The circumscribed form (Eisenlohr's case), in which the lesion is confined to a limited area. 2. A form in which paralysis and atrophy en masse occur quickly, show a tendency to arrest or to complete restoration, and may possibly be the result of acute or chronic infection (Landouzy and Dejerine's case). 3. A form which progresses slowly and irresistihly with atrophy of nerve cells without secondary atrophy of peripheral nerves (Dreschfeld's case) or with this atrophy (Oppenheim's case).

Oppenheim, in a later paper, does not accept as cases of chronic or suhacute anterior poliomyelitis those referred to by Nonne, and it seems to me that $\mathrm{O}_{\mathrm{ppenheim}}$ is right in this opinion.

Eisenlohr's case' was remarkable on account of the limitation of the process. The weakness and atrophy affected only the right upper limb and persisted about five years. The nerve cells were degenerated only in the right anterior horn between the sixth cervical segment and the first thoracic. The white matter was normal. It is difficult to decide why this case was regarded as one of subacute anterior poliomyelitis and not as one of progressive spinal muscular atrophy.

Dreschfeld ${ }^{2}$ regarded the case he reported as one of chronic anterior poliomyelitis. Weakness began in the right foot and leg. The tendon reflexes of the upper limbs were very prompt. The nerve cells of the anterior horns were much degenerated. Lateral sclerosis was found in the cervical region. It seems doubtful whether this should he regarded as a case of amyotrophic lateral sclerosis or as one of chronic anterior poliomyelitis.

Landouzy and Dejerine' did not regard their case as one of chronic anterior poliomyelitis.

A case that probably should be classed as one of chronic anterior poliomyelitis with necropsy was reported by Richard Ewald."

The case that Nonne reports began with weakness in the left shoulder and left upper arm. Atrophy occurred at the same time as the paralysis or followed soon after. In the last months of the disease pains were felt in the upper part of the upper limbs and in the thighs. Nonne' found some degeneration of peripheral nerves, as well as of nerve cells, in the spinal cord, and he refers to the fact that in Oppenheim's case the hypoglossal and spinal accessory nerves and the nerves within muscles were not entirely normal. Nonne found atrophy of nerve fihres in the white matter of the cord, in the pyramidal tracts as well as elsewhere, but not as symmetrical degeneration.

1 Nenrologisches Centralblatt, 1889, p 609.

- Revue de méd., 1882.

* Brafn, 1886, p. 178

- Ed Fall ron Pollomyellele anterior chronles, Insugaral Disscrtation, Marbarg, 1899.

Dentsche Zeltschif $\mathrm{f}$ Nerronheakunde, 189, Bd. L. p. 256. 
In Darkschewitsch's ${ }^{2}$ ease wcakness and atrophy developed gradually in tbe muscles of the upper limbs, neck, back, and partly in the lower limbs. The nerve cells of the anterior horns of the cervical and thoraeie regions were diminished in number, and there were numerous hemorrhages which seem to have been in the gray matter of the cord. Rarefaction of the lateral and posterior columns was observed. It is difficult to determine from the brief report why this was regarded as a case of ehronic poliomyelitis and not as one of progressive spinal muscular atrophy.

In Oppenheim's seeond case of chronic anterior poliomyelitis the weakness began in tbe right sboulder and rigbt upper arm, and after a year extended to the corresponding parts of the left upper limh. Atrophy soon followed the weakness. Parnesthesia was felt in the fingers in the beginning of the disease. The nerve cells of the anterior horns of the cervical and thoracic regions were much degenerated. The columns of Burdach were also degenernted.

In the case reported by A. Dutil and J. B. Charcot," the symptoms began with weakiness in the upper limhs. The vessels of the cord were thickened and some small recent hemorrhages were found in the cord. This is the same case that J. B. Charcot later reported
alonc.

In J. B. Charcot's two cases of chronic anterior poliomyelitis there was some degeneration of the anterior fundamental fascieulusi. e., of the fibres near the anterior lorn. These cases possibly might be regarded as exumples of progressive spinal muscular atrophy.

It is difficult two understand why Dejerine's ${ }^{5}$ two cases should be regarded as examples of chronic anterior poliomyelitis and not of progressive spinal muscular atrophy, if a sbarp distinction is maintained. In one case there was a questionable sclcrosis of the interior portion of the right lateral column.

Nonne," in 1896, recognized as eases of chronic anterior poliomyelitis with neeropsy the two cases of Oppenheim, the two eases of his orm, the case of Darkschewitsch, the case of Dutil and J. B. Charcot, and the two cases of Dcjerine.

In Nonne's second case the weakness began in the shoulder muscles. The nerve cells of the anterior horns were much degenerated and rarefaetion of the white matter was seen in the anterior, lateral, and posterior columns. The bloodvessels were not distinctly altered. He attrihuted the poliomyelitis in this case to diabetes. Nonne refers to the slight changes in the white matter ohscrved in Oppenheim's two cases, in his own two eases, in

\footnotetext{
1 Nienrologtsches Centralbhth, 1892. Bd. xl. p. 221.

Archir f. Prjchlatrle, 1892 Bd. xxir. p. Bm.

Ie progris medical, sinres 17, 2591, p 185

Archites de medecine expiritoentsie, 1385, rol. rii. p. It1.

- Comptes-rendus heb. des shances de la Soc. de bologie, 1825, p. 188.

- Berltuer klin. Wochengchitif, Harch 9, 1986, p.207.
} 
Darkschewitsch's case, in Dutil and Charcot's case, and in one of Dejerine's cases.

In P. Schuster's atypical case of chronic anterior poliomyelitis, which was complicated hy degeneration of the posterior roots and of the columns of Burdach, the patellar reflexes were much exaggerated. The explanation was supposed to be found in the slight alteration of the lateral columns.

Max Bielschowsky' says there are very few cases of chronic anterior poliomyelitis reported that show evidences of inflammation. In Bielschowsky's case the weakness began in the lower limbs, in the peroneal distribution, as in the case Dr. Moleen and I report. He says that contrary to the diagnosis of neural atrophy (peroneal type) were the later developments of the disease and the ahsence of subjective and ohjective disturhance of sensation. Contrary to progressive spinal muscular atrophy were the location of the atrophy, the relatively rapid development of the symptoms, and the early loss of function in the diseased muscles. Hemorrhages were found in Bielschowsky's case in the anterior horns from the lumhar to the upper cervical region. In some places the red blood corpuscles had disintegrated, blood pigment was present, and reactive processes had occurred about some of the hemorrhages. These hemorrhages were regarded as evidences of inflammation. Slight degeneration was secn in the crossed pyramidal tracts of the spinal cord as high as the pons, but was detected only by the Marchi mothod and was slight, exactly as I have found in the specimens studied by me. Bielschowsky observed slight perivascular round-cell infiltration and newly formed bloodvessels. The hypoglossus nuclei also were affected. This case resemhles ours very closely, al though the disease in Bielschowsky's case lasted nine years. The tongue was also weak and atrophied. No statement is made concerning the condition of the patellar reflex until late in the disease, when the atrophy was intense.

In Grunow's case the symptoms seem to have existed ahout nine months. The weakness began in the right foot and peroneal palsy developed. Pain was felt in the shoulders and back. Progressive spinal muscular atrophy was excluded because the weakness began in a lower limh, because of the wide extent of the process, the implication of intercostal muscles, and the relative rapidity of development. As in our case, peroneal palsy was among the earliest signs of the disease. The pain in this case is noteworthy. Cellular infiltration was found ahout the arteries of the anterior fissure and ahout some of the vessels of the anterior horns and white matter. Necrotic foci were present in the crossed pyramidal tracts, and there were some small hemorrhages in. the gray matter of the cord.

1 Feurologitehea Centralblats, 1897, Ed. rv1, pp. 312, 392, 49.

- Zeltschrir f. kHo. Hed.e 1899. Bd. xxxyli. n. 1.

- Deutsch Zeltschrif C. Nerrezhellkunde, 1901, Bd. Ix. p. s39. 
The nerve cells of the anterior borns were much degenerated. Degeneration was found in the anterior and lateral columns. . . .

Bruining ${ }^{1}$ has observed chronic anterior poliomyelitis in father and son, and in one of the cases obtained a necropsy. In neither case were there periods of abrupt increase in the symptoms. The weakness seemed to be proportional to the atrophy. In the father.tbe wcakness and atrophy began in tbe right thigh and then the shoulders became implicated. In the son the atrophy began in the muscles of the neck and extended to the shoulders and.upper limbs. The neric cells of the anterior horns throughout the cord were degenerated, but no signs of inflammation were found. The capillaries of the cord were congested and in some places blood corpuscics were found in the tissues about the vessels. Bruining is not inclined to makc sbarp distinctions between chronic anterior poliomyelitis and progressive spinal muscular atrophy.

Rossolimo, in reporting a casc of chronic anterior poliomyelitis with syringomyelia, recognized that somewhat exaggerated patellar reflexes may occur in anterior poliomyelitis, and refers to the cases of Darkschcuitsch and Schuster. He recognizes as cases of chronic anterior poliomyelitis only those of Oppenheim, Nonne, Darkschewitsch, Schustcr (not a pure case), Biclschowshy, and R. Ewald.

Oppenheim, in speaking of chronic anterior poliomyelitis in his tcxt-book, says exaggeration of tcadon refexes alone is not sufficient to make the casc onc of amyotrophic lateral sclcrosis, as eraggeration of reflexes may occur in ncurasthenia.

In the monograph on poliomyelitis written by Elis Lövegren, the author reports a casc of subacute poliomyelitis with necropsy. Tbe wcakness began in the fingers and was followed in two or three months by atrophy of the hands. The paresis and atropby became widespread. The patellar reflexes were exaggerated. The nerve cells of the anterior horns of the spinal cord and of nuclei of motor cranial nerves were dcgenerated. Vessels with thickened walls were found in the spinal cord, but there was no round-cell infiltration. The white matter of the cond was said not to be involved and tbe pyramidal tracts to be intact. The metbod of Marchi was not employed. The anterior roots and peripheral nerves showed slight atrophy. A cavity in a limited area was found in one anterior horn.

Lövegren refers to two cases of subacute or chronic poliomyelitis with necropsy reported by Philippe and Cestan," in wbich a sligbt sclerosis of the anterolateral columns was found; and to a case with necropsy reported by Raymond and Philippe." I have not been able to obtain the paper by Philippe and Cestan.

\footnotetext{
1 Deuteche Zeltechrif t. Nerredbellkande, 1901, Bd. Ixvil. p. $\$ 9$.

- Aeurologisches Centralblatt, 1905, p, s5s.

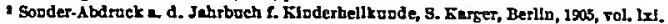

4 IIII. Congria loterantional de medecine, Parly, 1900, comples-rendas, weetion de setrologie, P. 271.

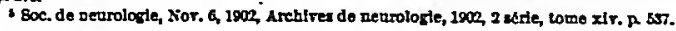


The case of chronic poliomyelitis very briefly reported hy Raymond and Philippe' is as follows: The disease began at the age of fifty-two years in the extremities of the lower limbs, and is said by the authors to have heen the first case of the kind. The anteroexternal muscles of the legs first showed atrophy and the weakness progressed simultaneously with the atrophy. The poliomyelitis was strictly limited to the nerve cells of the anterior horns, The anterior roots and peripheral nerves were secondarily affected. No mention is made of the employment of the method of Marchi or of the condition of the tendon reflexes.

The case ohserved clinically hy Dr. Moleen and studied from the pathological aspect by me may properly, I think, be regarded as one of chronic anterior poliomyelitis. The commencement in one lower limb, the paralysis preceding the atrophy, the comparatively rapid development of the symptoms, the ahsence of sensory disturhances, and the pathological findings justify this diagnosis. The prompt tendon reflexes are unusual, hut it is probable that Bielschowsky's patient would have shown the same condition if these reflexes had been ohserved earlier in the disease. The patellar reflexes were exaggerated also in Lövegren's case. The degeneration of the crossed pyramidal tracts in our case was very slight and perceptible only by the Marchi metbod. When the Weigert method was employed no suspicion of degeneration of the pyramidal tracts could be entertained. The case, however, sbows that the distinctions between amyotrophic lateral selerosis and chronic anterior poliomyelitis are not always to be sharply made. The Marcbi method does not seem to have been emplojed in the examinations of many of the cases of cbronic anterior poliomyelitis reported.

It is noteworthy that pain was recorded as present in the cases of Nonne (Case I.) and Grunow, and that paresthesia occurred in Oppenbeim's second case.

MYYOCLONUS MULTIPLEX: WITH REPORT OF A CASE.

$$
\begin{gathered}
\text { Br D'Orsay Hecht, M.D., } \\
\text { or culcago, }
\end{gathered}
$$

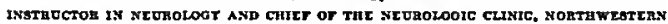
UATV ERATF YEDICAL BCHOOL, AssOCLTE ATTENDING NEOHOLOOLFT TO THI COOK COCNII INSTITUIONB AT DCNNIXa, 1LI.

Histonical. Since Friedreicb in 1881 (Virchow's Archiv) reported for the first time his case of "paranyoclonus multiplex," some cases similar and many more dissimilar to it have found their way into the literature under the same appellation and caused endless con- 